\title{
Analyzing the Properties of Saliva to Act as a Viable Fuel Source and Its Capabilities to Interact with Microbial Fuel Cell (MFC) Powered Theoretical Diagnostic Devices Beneficial to Low-income Communities
}

\author{
Krisha Dhall, BSc Student [1]*, Krismaa Rajasuresh, BSc Student [2] \\ [1] Department of Health, York University, Toronto, Ontario, Canada M3J 1P3 \\ [2] Department of Science, York University, Toronto, Ontario, Canada M3J 1P3 \\ *Corresponding Author: krisha.dhall@yahoo.ca
}

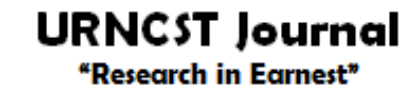

\begin{abstract}
Introduction: The WHO has stated that about $50 \%$ of the world lacks access to secure and continuous supply of electricity, heavily impacting the healthcare industry in these countries. Microbial Fuel Cells (MFCs) can be a low cost-efficient energy source capable of powering medical devices in low-income countries. Due to the components and impurities found in saliva, this biofluid can behave like an electrolyte and a viable fuel source to power the MFC. With this capability, saliva has the potential to power micro-gadgets with microbial fuel cells capable of degrading the components of saliva. Thus, this study explores saliva's potential to act as a fuel source to power microbial fuel cells within medical diagnosis devices.

Methods: A systematic review was conducted through primary and secondary research articles exploring and comparing the use of saliva as an energy source compared to other biofluids. Key terms focused for meta-analyses include: 'semiconductors', 'saliva', 'microbial fuel cells', 'point-of-care'.

Results: Previous research has discovered that lysozyme enzymes present in saliva can create an electrical charge that can successively power biomedical devices. Researchers have also created paper-based batteries containing frozen exoelectrogenic cells, powered by the bacterial degradation of human spit. Saliva has been demonstrated to contain similar biomarkers to urine, a successful diagnostic biofluid, and can therefore be used as a diagnostic biofluid as well.

Discussion: Given saliva's capabilities, a hypothetical diagnostic device powered using saliva as the biofluid, was designed. Bacteria break down the saliva, allowing protons to travel from the anode to the cathode resulting in electricity. It was determined that graphite would be the most cost-efficient and energy producing electrode material for the device. In addition, this electricity that is produced will power the diagnostic device attached.

Conclusion: Saliva can act as a fuel source, capable of powering diagnostic devices using microbial fuel cells with saliva. These properties can be beneficial to many people who do not have access to preliminary diagnosis. This can result in immediate treatment and help prevent further spread of diseases, vital for those in low-income countries. Broad scale applications of using saliva can be directed towards exterior lighting systems and powering larger medical devices.
\end{abstract}

Keywords: saliva; semiconductor; microbial fuel cells; point of care; urine; diagnosis; bio-battery

\section{Introduction}

Since the rise of global warming [1], finding more ways to produce electricity has been a priority for scientists [2]. It is important to establish secure methods for clean electricity as it can directly impact healthcare and the ability to combat diseases. The lack of sufficient electricity to healthcare facilities increases the opportunity of diseases and puts members of impoverished communities at high health risks [3]. To put in perspective the widespread shortage of electricity and healthcare, almost $50 \%$ of the world do not have access to basic healthcare necessities [4] and poorly regulated laboratories [5], as $~ 940$ million people lack access to electricity [6], which can increase the risk of infectious diseases that wipe out more than 17 million people annually [4].

Although a huge number of people face this disadvantage, semiconductors, a material that has electrical conductivity between that of a conductor and insulator, with well known efficient power distribution and low cost [7] can be used. For example, Poly(3,4-ethylenedioxythiophene): poly(styrene sulfonate) (PEDOT:PSS) is a highly conductive and transparent polymer [8] semiconductor [9]. The PEDOT:PSS polymer consists of PEDOT with positive charges and PSS with negative charges [10]. Doped PEDOT:PSS allows for band-gap narrowing and increase in conductivity efficiency [11]. When atoms are connected 
UNDERGRADUATE RESEARCH IN NATURAL AND CLINICAL SCIENCE AND TECHNOLOGY (URNCST) JOURNAL Read more URNCST Journal articles and submit your own today at: https://www.urncst.com

creating a molecule, the wavefunctions of valence electrons overlap [12]. The orbitals then split into different energy levels [12]. The orbitals are placed closely and look like a band with the minimum energy required to excite the electrons for conductivity [12]. Between the bands are bandgaps where energy does not exist [12]. Semiconductors have smaller band-gaps allowing for increased electrical conductivity, compared to insulators [12]. The process of doping a semiconductor is introducing impurities with atoms that have excess valence electrons that can be donated [12], for example acids like $\mathrm{H}_{2} \mathrm{SO}_{4}$ [13]. Therefore, increasing the doping level increases the narrowing of band-gap [11].

The human body is host to an abundance of natural fuel sources that have enough power to generate electricity to influence nonhuman mechanics [14]. Urine, for example, is mildly acidic, ranging from a $\mathrm{pH}$ of 6 to 7.5 [15] because it contains electrolytes, organic and inorganic solutes dissolved in 95\% water [16]. Acids [17] and electrolytic substances [18] have the potential to conduct electricity $[17,18]$, and due to the presence of impurities urine can conduct electricity [16]. An often disregarded and non-invasive biofluid is saliva. Saliva is a slightly acidic biofluid that contains several electrolytes, proteins, and biological materials [19]. With similar properties to urine, saliva also has the ability to execute electrical properties powering micro-and-macro-gadgets [20]. Saliva also has storage advantages by undergoing exoelectrogenic lyophilization, the process of freeze drying the biological fluid [21]. The two terms 'exoelectrogens' and 'lyophilization' mean biological substances capable of transferring electrons on the extracellular surface [22] and the process of freezing these exoelectrogens [21], respectively. Overall, saliva has the ability to allow lyophilization of exoelectrogens thereby allowing storage and accessibility at point of care [20]. Storage abilities are important when considering point of care (POC) medical testing in order to bring the environment of diagnosis and immediate treatment closer to the patient [23] without waiting for the condition to worsen.

Moreover, saliva and urine are used as non-invasive methods to diagnose different conditions. Despite urine being easily accessible and non-invasive, similar to saliva, it has been used more often as a diagnostic tool. This is because urine has been used since the early 16th century as a simple diabetes diagnosis because after evaporating water from urine, excess salt present gave doctors a conclusion about diabetes presence [24]. Urine is used for checking stress levels by measuring biomarkers - compounds that indicate cellular processes - including cortisol and testosterone, and measuring the presence of myoglobin, a protein that holds oxygen in the muscle [16]. To measure such biomarkers in urine, the Enzyme-Linked Immunosorbent Assay (ELISA) [25] is used. ELISA is an assay that can identify the presence of antigens, antibodies and hormones in a solution, which can be associated with underlying health problems [25]. ELISA test is done using a polystyrene plate which has a primary and secondary antibody that attaches to different proteins [25]. The primary antibody binds to the specific protein whereas the secondary antibody binds to a nonenzyme-conjugated primary antibody [25]. In order to detect the protein in the plate, substances such as horseradish peroxidase, a hydrogen peroxide, can be used giving the protein of interest a blue color [25].

Since urine is excreted unlike blood and other bodily fluids, it can be tested easily. There is increased importance inflicted towards non-invasive diagnostics because it allows for less physical interference, decreased pain, prevents emotional stress [16], and is overall inexpensive [26]. In the hospital, invasive methods such as drawing out blood and tissue biopsies [16] are used to diagnose and treat patients. Similarly, tears in the skin from a biopsy or needle, or being under anesthesia during a medical procedure can cause disruption to an individual's daily routine. This is especially impactful for people living in under-developed and barren nations where getting the basic needs like food and water requires a lot of movement and is not readily accessible [16]. When these invasive diagnosis methods are not easily accessible, saliva and urine can be used as alternative bodily fluids for examination despite these fluids acting as only a precursor for possible underlying conditions. Similarly, the cost to bring surgical tools, needles, and doctors to retrieve the samples would be reduced to a negligible amount [16]. Along with being a non-invasive diagnostic biofluid, saliva can be stored in MFC's to be used in third world countries.

Saliva's chemical properties, storage and easily attainable methodology allows it to be used in powering MFC's, which are battery cells powered by microbes (a bacteria [27]) [20]. Fuel cells are like a battery that uses a fuel source to create electricity [28] through the movement of electrons via oxidation and reduction reactions [27]. MFC's have bacteria that break down organic compounds, which is present in both saliva and urine, thereby creating an electrical current to power other devices [29]. It is hypothesized that with saliva's ability to act as a noninvasive diagnostic biofluid and an efficient fuel source for MFC's capable of exoelectrogenic lyophilization for point of care diagnostics, a device can be designed to function using saliva powered MFC's while simultaneously using the same sample of saliva to diagnose the patient. This design can provide poverty-stricken communities with low cost and efficient diagnostic instruments that do not require more than $1.07 \mathrm{ml}$ of saliva - the amount of saliva present in the mouth at any given time [30] to conduct the electricity required to power the device.

Since 17 million people annually are at risk of dying due to infectious diseases [4], small diagnostic devices can be used to check the body for any foreign microorganisms. And since 940 million people lack the access to electricity [6] and have less resources to create electrical poles and electrical sockets, human bodies natural fluids such as saliva, can be used to conduct electricity for small devices. Saliva can power MFCs and thus saliva can indirectly be used to power the diagnostic device while the device analyzes the 
saliva for different conditions the person may have. Such a self-powering saliva-based device can reach many people and help them see if they have any underlying illness before it worsens while not needing to rely on the government for building electrical ports and medical test centers.

\section{Methods}

To focus on this research, the following search engines were used: York University Library, Google scholar and Google with the subsequent keywords: 'band-gap', 'microbial fuel cells', 'semiconductor', 'point-of-care', 'electricity shortage', 'worldwide infectious disease deaths', 'lyophilization', 'diagnostic device' and 'exoelectrogenic'. This paper used primary and secondary papers from 1990 to 2021. Since urine and saliva are easily accessible and noninvasive both their electrical and diagnostic properties are compared.

\section{Results}

There is experimentation underway regarding paperbased bio-batteries that are saliva activated such as a disposable bio-battery to be used for POC [20]. It was discovered that a single paper-based lyophilized exoelectrogenic bacterial cell has both electronic and fluidic structure for the anode storage, ensuring that all layers were oxygen tight, as well as an air-cathode was used [20]. The paper was enabled with conductive components to create the paper base using poly(3,4-ethylene dioxythiophene):polystyrene sulfonate (PEDOT:PSS) [31]. This polymer increases the conductivity of the overall device and exhibits an average experimental band-gap of $1.5 \mathrm{eV}$ [32]; band-gap is subject to change with the varying dopant used. This enables the paper to maintain its pores and hydrophilicity allowing bacterial attachment and is not reduced due to freezing [31]. The example of such a device, Figure 5, can be found on page 6 of Mohammadifar's manuscript [20].

Referring to Figure $2 b$, found on page 3 of Mohammadifar and Choi's manuscript [20], a direct conclusion was made that as the storage time of the paperbased bio-battery increased, the ability to retain the maximum power density decreased. This shows that saliva can only be stored for approximately 3 weeks as seen from Figure $2 b$, before the power density decreases significantly [20]. However, the significant decrease was due to changes in humidity and temperature during storage [20]. Analyzing the graph, from Figure $2 \mathrm{a}$, found on page 3 of Mohammadifar et al.'s manuscript, the results show the average power generated by the bio-battery with freeze-dried exoelectrogens is $0.396 \mu \mathrm{W} / \mathrm{cm}^{2}$ [20].

The MFC using saliva for creating electricity is known as a two-chamber cell. The anode and cathode are in plexiglass chambers and copper wires connect the two through a Nafion membrane (made of perfluorosulfonic acid [33]) allowing only protons to pass through [34]. The MFC will use platinum for the electrodes however, such a rare metal will increase the cost of the MFC [33]. In the MFC, the bacteria will break down saliva and its protons will flow from the anode to the cathode [29], generating electricity for the battery.

Diagnostic devices using urine as diagnostic fluid, could also use saliva because of similar biomarkers present in both biofluids. For example, when using the ELISA assay testing for inflammation, neopterin is the biomarker examined in urine and saliva [16]. Another example of similar biomarkers found in urine and saliva include cortisol and testosterone identifying stress [16]. Testosterone levels are examined using ELISA from both urine and saliva, however, cortisol, a protein hormone [35] is detected in saliva using ELISA and in urine using High Performance Liquid Chromatography $[36,16]$. Other biomarkers tested from saliva include salivary lactate showing the amount of lactic acid present and salivary antibodies testing for infections created by $\mathrm{H}$. pylori bacteria [35].

Inspired by Figure 5 of Mohammadifar and Choi's manuscript, and Figure 1 [20] of Mansoorian et. al.'s manuscript [34], a theoretical device can be constructed when combining this two-chamber MFC [29] with diagnostic devices and considering saliva as the power source and diagnostic fluid (Figure 1). The person will first spit into a pump that will send saliva to both the MFC and the diagnostic device. The sample of saliva that is used for diagnosis purposes will be tested using the device's capabilities which vary according to the device attached. The results of the diagnosis will display onto an attached screen. The hypothetical MFC would have the anode and cathode chambers separated by wax [20] or Nafion membrane [34] allowing effective proton exchange [20]. 
UNDERGRADUATE RESEARCH IN NATURAL AND CLINICAL SCIENCE AND TECHNOLOGY (URNCST) JOURNAL Read more URNCST Journal articles and submit your own today at: https://www.urncst.com

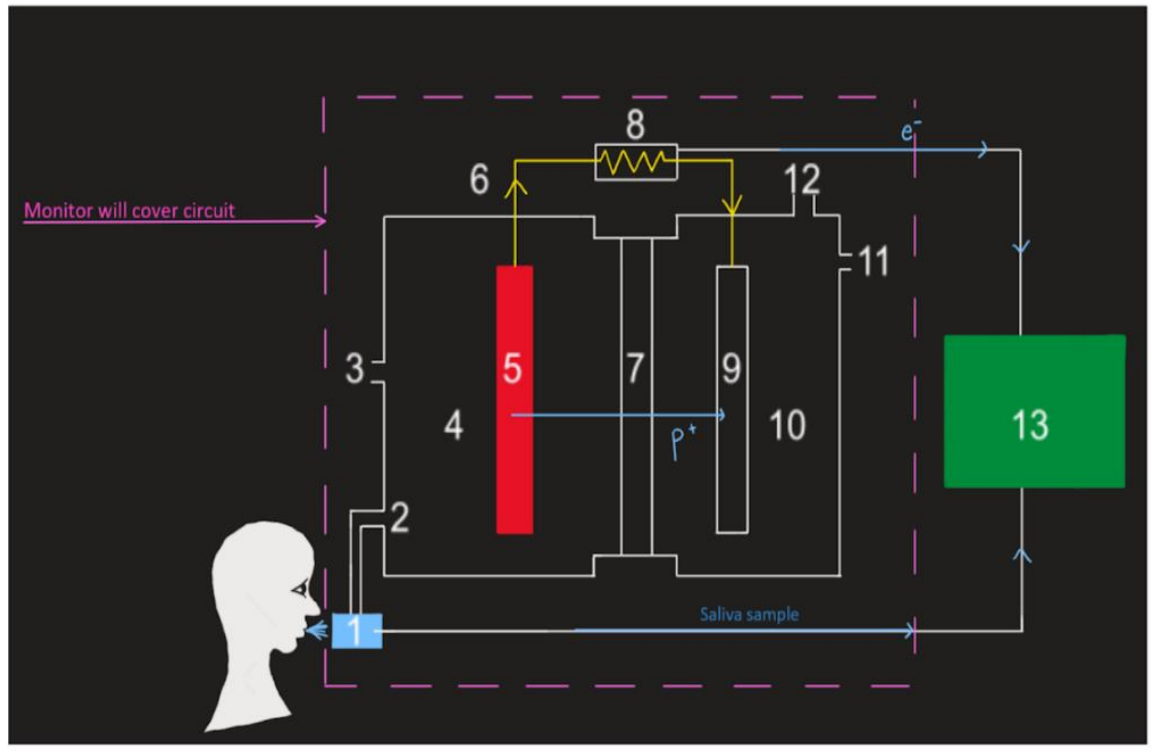

1) Peristaltic pump

2) Influent

3) Effluent

4) Anodic chamber

5) Anode electrode

6) Copper wire

7) Proton exchange membrane

8) Digital multimeter

9) Cathode electrode

10) Cathodic chamber

11) Buffer influent

12) Exhaust

13) Diagnostic device

Figure 1. A 2D theoretical schematic of a microbial fuel cell layout. The MFC would use wax [20] or a Nafion membrane [34] to separate the anode and the cathode in a PEDOT:PSS reservoir [20] to act as a proton exchange membrane [34] and allow the flow of protons to be more effective [20]. The bacteria present in the MFC will break down saliva to create the flow of protons [20]. Within each plexiglass chamber sits an anode and a cathode sequentially connected to a digital multimeter via a copper wire. The anode and cathode would be made of graphite $[20,34]$ as it produces a high amount of energy with a low cost [37]. The saliva imputed into the peristaltic pump will be divided between fuelling the MFC and the diagnostic tool. There will be an overlaying monitor screen eliciting the results.

\section{Discussion}

The purpose of this study was to explore saliva's capability to act as a natural fuel source to power MFC's. It was hypothesized that a device could be designed to function as a diagnostic tool powered by saliva. In this research, urine and saliva were compared as common non-invasive biofluids with biomarkers available for many conditions. According to the diagnostic device created in Figure 1, urine could also be used instead of saliva as urine contains electrolytes, organic and inorganic solutes dissolved in $95 \%$ water [16]. However, no device has been made that uses urine as a power source. To support saliva being used as an energy source and diagnostic device, a study was performed to find the preference of saliva among other bio-fluids to be used for different tests [38]. The study concluded that $85 \%$ of clinicians in Ibadan, Nigeria preferred saliva as a good bio-fluid to test for diseases as spitting saliva into a container for testing is convenient [38]. If the patient is dehydrated, limited urine is produced to power the MFC and obtaining urine is more difficult if there is no access to clean washrooms, whereas saliva can be obtained anywhere. Despite urine being more than $99 \%$ accurate at drug tests and saliva having $99 \%$ accuracy, saliva drug tests require smaller samples and simpler devices than urine [39].

The theoretical device is designed to function off saliva which is used as the fuel source and diagnostic specimen. As mentioned previously it is evident that saliva contains sufficient biomarkers that can provide adequate point of care

Dhall et al. | URNCST Journal (2021): Volume 5, Issue 6

DOI Link: https://doi.org/10.26685/urnest.261 testing [40]. Semiconductors allow for low-cost construction, low power usage, long-lasting energy, is minimizable in size and integratable [41]. Since the device would be using saliva as a fuel source, accessing the energy will be quick. This device is designed to provide accessibility and affordability of health care for low income communities and diagnosis at POC. POC testing is beneficial because it provides earlier diagnosis of ailments or illnesses, minimizes patient travel time to hospitals for urgent care, low hospital or lab waiting time, immediate results, and economic benefits [42]. Although saliva can be used to detect systemic diseases [43], this device is designed for primary diagnosis and further testing is required before more severe treatments like surgeries.

The MFC is similar to the paper-based bio-battery as it uses bacteria to break down organic matter. The protons released by the bacteria travel from the anode to the cathode via a conductor [29]. However, MFC's generally have a continuous supply of electricity as the organic substrate is restored, while the bio-battery has a limited flow of electricity because the organic matter is not replenished [29]. Therefore, to create a device that can be reused for diagnosis while generating electricity, a MFC is a better option than the bio-battery. The challenge faced by MFC's is the cost of construction materials as platinum is a rare metal that is used in the cathode and anode [33]. To overcome this disadvantage, copper, gold [44] and ferricyanide [29] are some metals that can be used instead of platinum as a cathode 
UNDERGRADUATE RESEARCH IN NATURAL AND CLINICAL SCIENCE AND TECHNOLOGY (URNCST) JOURNAL Read more URNCST Journal articles and submit your own today at: https://www.urncst.com

but the former does not give the same effectivity rate as platinum [44] and ferricyanide despite generating 1.5-1.8 times more power than platinum, needs to be generated chemically [29]. Other cathodes using iron and cobalt as organic mixtures may replace platinum, but their durability is not well studied [45]. The hypothetical device should use graphite rods [34] making the device more cost-effective as graphite is cheaper and generates a high amount of electricity [37].

Normal batteries in remotes for example, could also be used as they are simple to put in the device. However, once these batteries run out, they need to be charged. If the diagnostic device is being used in third world countries, then having access to electricity is not very common. MFC's, unlike batteries, do not need to store electrical energy as they can directly create it [46] by using saliva, for example. This process has a higher efficiency rate of $40 \%$ to $60 \%$ whereas batteries have an efficiency rate of less than $40 \%$ [46]. Like normal batteries, saliva can also be stored for longer periods of time. If optimal levels of humidity and temperature are maintained, a bio-battery can elicit a constant power density output of $0.396 \mu \mathrm{W} / \mathrm{cm}^{\wedge} 2$ [20] whereas, MFCs generate $1540 \mathrm{~mW} / \mathrm{m}^{\wedge} 2$ [29] power density, thereby releasing more power for the device. As in Figure 1, the MFC will have PEDOT:PSS as the semiconductor surrounding it which will increase the power output of the device by doping. The level of doping increases with the progression of miniaturization [4]. It can be noted that an MFC is a small cell; it would require a significantly increased level of PEDOT:PSS doping. As doping levels of PEDOT:PSS increase, it is anticipated that the overall conductivity of the MFC should increase as well.

MFC's use bacteria that break down organic matter like saliva to create electricity [29]. Protons flow from the anode to the cathode once the bacteria produces protons by breaking down the organic matter [29]. The hypothetical device created in Figure 1 uses a similar method where an anode and cathode will be divided by a Nafion membrane [34] and the device will use bacteria to break down saliva and produce protons to create a current. The flow of protons will be connected to the diagnostic device attached which will be diagnosing the saliva from the peristaltic pump. Simultaneously, the flow of protons will also power the monitor displaying the results. The hypothetical device will be able to use saliva's chemical ability to fuel the MFC powering the diagnostic device. The hypothetical device would be an improved version of the MFC by Logan et al.'s [29] and Mansoorian et al.'s [34] as it will be able to diagnose the person while using their saliva to generate the power to do so.

Although the electrical component of the hypothetical device is cheaper, adding the diagnostic device raises the cost of the whole device. A monitor to display the results of the diagnoses will also increase the overall cost of the device. The diagnostic device will only be able to give baseline values which have to be analysed by the medical professional and to actually give medication and treatment to the patient, further tests and treatments need to be carried out to improve the patient's well-being.

Using saliva as a fuel source can be expanded to larger scale devices theoretically, where under optimal conditions singular MFCs can be combined into a circuit to generate power for outdoor lighting. This supposed MFC could also contain 2 electrodes: an anode, as well as an air-cathode [31]. The carbon anodes could be connected to sewage systems providing a natural flow of bacteria to treat the MFC before the saliva is introduced [31]. A creative use for such a system is by utilizing spit, and dog saliva to produce electricity in third world countries such as India. In stray dogs' salivation can be caused by many factors like the scent of food, or other biological problems [47]. Although canine saliva may have different components, the MFC can be tested to see if dog saliva is as effective as humans.

As WHO stated that $50 \%$ of the world doesn't have access to basic healthcare necessities, using freeze-dried cells and MFC's as in Figure 1, in medical devices and using saliva to generate power will be cost efficient. For example, in a dentist's office, a saliva ejector is used to suction out the saliva which can be collected and used to power the same device and other devices such as the cavitron (a device that cleans plaque from the teeth [48]). It has been shown that saliva can be used to power a LED for 20 minutes [49]. This is especially useful in low-income countries where cheaper sources of electricity are beneficial. Instead of the government or private institutions sending medical equipment yearly to treat lower-income households, the hypothetical device can be used for diagnosis.

\section{Conclusions}

Healthcare worldwide can be made better by initiating adequate diagnosis procedures to prevent the spread of disease, providing small scale lighting and electricity to healthcare facilities and communities. In theory, since saliva is capable of exoelectrogenic lyophilization for point of care diagnostics and is a non-invasive biofluid with efficiency to power a semiconductor for a MFC, a device can be designed for simultaneous functions of power generation using saliva as the fuel source, and diagnosis. The intent of the research protocol was to explore the use of saliva as a fuel source to power diagnostic POC devices. It is anticipated that this prototype can use saliva to generate power to assist developing countries with primary POC diagnosis. The hypothetical prototype uses the knowledge from previous devices and improves and combines the functions of semiconducting and diagnostic devices. The importance of the research protocol is to improve electricity and healthcare sustainability as well as reduce the problems faced by people in developing nations by creating a self-powered diagnostic device. The protocol also combines the scientific knowledge presented in other research, enhancing, and promoting questions that can be associated with semiconductors. A fuel source brings in the aspect of the natural sciences, by using 
UNDERGRADUATE RESEARCH IN NATURAL AND CLINICAL SCIENCE AND TECHNOLOGY (URNCST) JOURNAL Read more URNCST Journal articles and submit your own today at: https://www.urncst.com

saliva to power devices used in the medical field and the device that diagnoses different diseases provides an amalgamation of clinical sciences and technology.

Further research can be done so that saliva can power large scale devices like exterior lighting using human and possibly dog saliva. Dentists also encounter large amounts of human saliva when using saliva ejectors, and studies can be done to use this saliva efficiently to power the device. The goal is to create an affordable energy source available to all people around the world to obtain adequate primary diagnosis, and improve healthcare, electricity sources and be as eco-friendly as possible.

\section{List of Abbreviations Used}

WHO: World Health Organization

POC: point of care

ELISA: Enzyme-Linked Immunosorbent Assay

PEDOT:PSS: poly(3,4-ethylene

dioxythiophene):polystyrene sulfonate

MFC: microbial fuel cell

LED: light emitting diode

\section{Conflicts of Interest}

The authors, Krisha Dhall and Krismaa Rajasuresh, declare that they have no conflicts of interest.

\section{Ethics Approval and/or Participant Consent}

This systematic review did not require any participants or the use of any animals, thus, no ethics approval was required.

\section{Authors' Contributions}

$\mathrm{KD}$ : involved in the introduction, methods, results, edited discussion, conclusion, created and formatted the references. Also made contributions to the design of the study, analysed the data, drafted the manuscript, edited the manuscript, and gave final approval of the version to be published.

KR: involved in the introduction, edited methods, edited results, Figure 1, discussion, conclusion, created and formatted the references. Also made contributions to the design of the study, analysed the data, drafted the manuscript, edited the manuscript, and gave final approval of the version to be published.

\section{Acknowledgements}

We would like to acknowledge Bi-Ru Amy Yeung for being our mentor and guiding us through the process of completing this systematic review. We would also like to acknowledge Ajen Kuganeswaran for assisting us through the revision of our initial draft.

\section{Funding}

This study was not funded.

\section{References}

[1] Health and Climate Change: Accounting for Costs [Internet]. Knowlton: Natural Resources Defense
Council; 2011 November [cited 2021 Mar 30]. Available from: https://www.nrdc.org/sites/default/files/ accountingcosts.pdf

[2] Hemminger J. New Science for a Secure and Sustainable Energy Future. 2008. https://doi.org/10.2172/964400

[3] Klinger C, Landeg O, Murray V. Power Outages, Extreme Events and Health: A Systematic Review of the Literature from 2011-2012. PLoS Currents [Internet]. Public Library of Science (PLoS). 2014. http://dx.doi.org/10.1371/currents.dis $.04 \mathrm{eb} 1 \mathrm{dc} 5 \mathrm{e} 73 \mathrm{dd} 1377 \mathrm{e} 05 \mathrm{a} 10 \mathrm{e} 9 \mathrm{edde} 673$

[4] Organization WH. Infectious diseases kill over 17 million people a year: WHO warns of global crisis [Internet]. World Health Organization. World Health Organization; 1996 [cited 2020 Aug 20]. Available from:

https://www.who.int/whr/1996/media_centre/press_relea se/en/

[5] Diagnostics for Developing Countries. Diagnostics [Internet]. 2015;5(2):200-9. https://doi.org/10.3390/diagnostics5020200

[6] Ritchie H, Roser M. Access to Energy. Our World in Data [Internet]. 2019 [cited 2020 Aug 21]. Available from: https://ourworldindata.org/energy-access

[7] Mcnerney R. The Editors of Encyclopaedia Britannica. Semiconductor [Internet]. Encyclopædia Britannica. Encyclopædia Britannica, inc.; 2021 [cited 2021 Mar 31]. Available from: https://www.britannica.com/science/ semiconductor

[8] University Y, Skabara PJ. The damaging effects of the acidity In PEDOT:PSS on semiconductor device performance and solutions based On Non-acidic alternatives. Materials Horizons [Internet]. 2020;7(7):1759-72. https://doi.org/10.1039/C9MH01978B

[9] Poly(3,4-ethylenedioxythiophene)poly(styrenesulfonate) 655201 [Internet]. Poly(3,4ethylenedioxythiophene)-poly(styrenesulfonate) 2.2-2.6\% in $\mathrm{H} 2 \mathrm{O}$, (high-conductivity grade). [cited 2021 May 13]. Available from: https://www.sigmaaldrich.com/ catalog/product/aldrich/655201?lang=en\&region=CA

[10] University Y, Nie W, Tsai H, Wang N, Huang H, Cheng Y, et al. PEDOT:PSS for Flexible and Stretchable Electronics: Modifications, Strategies, and Applications. Advanced Science [Internet]. 2019;6(19):1900813. https://doi.org/10.1002/advs.201900813

[11] University Y-F, Sernelius BE. Band-gap narrowing in heavily doped many-valley semiconductors. Physical Review B [Internet]. 1981;24(4):1971-86. https://doi.org/10.1103/PhysRevB.24.1971

[12] McGillivray D. Enhanced Conducting Polymer PEDOT:PSS/ Silicon Hybrid Solar Cells: Optimization of Thin Film Properties and Heterojunction 
UNDERGRADUATE RESEARCH IN NATURAL AND CLINICAL SCIENCE AND TECHNOLOGY (URNCST) JOURNAL

Read more URNCST Journal articles and submit your own today at: https://www.urncst.com

Interactions [thesis]. Vol. 49, Journal of Polymer Science Part B: Polymer Physics. 2019. p. 1-16.

[13] University Y, Yang K, Chen R, Zhou Y, Chen S, Zheng $\mathrm{Y}$, et al. The Role of Mineral Acid Doping of PEDOT:PSS and Its Application in Organic Photovoltaics. Advanced Electronic Materials [Internet]. 2019;6(1):1900648. https://doi.org/10.1002/aelm.201900648

[14] Plante A. How the human body uses electricity. University of Maryland [Internet]. 2016 [cited 2021 Mar 31]. Available from: https://www.graduate .umaryland.edu/gsa/gazette/February-2016/How-thehuman-body-uses-electricity/

[15] Bono MJ, Reygaert WC. Urinary Tract Infection. In: StatPearls [Internet]. StatPearls Publishing; 2020 [cited 2021 May 9]. Available from:

https://www.ncbi.nlm.nih .gov/books/NBK470195/

[16] Lindsay A, Costello JT. Realising the Potential of Urine and Saliva as Diagnostic Tools in Sport and Exercise Medicine. Sports Medicine [Internet]. 2016;47(1):11-31. https://doi.org/10.1007/s40279-0160558-1

[17] Ghosh JC. LXIX. - The electrical conductivity of acids and bases in aqueous solutions. J Chem Soc, Trans [Internet]. 1918;113:790-9. https://doi.org/10.1039/CT9181300790

[18] Siyavula. Electrolytes, ionisation and conductivity. In: Physical Sciences Grade 10 [Internet]. Siyavula; [cited 2021 Mar 30]. Available from: https://intl.siyavula.com/ read/science/grade-10/reactions-in-aqueous-solution/18reactions-in-aqueous-solution-03

[19] Kubala E, Strzelecka P, Grzegocka M, Lietz-Kijak D, Gronwald H, Skomro P, et al. A Review of Selected Studies That Determine the Physical and Chemical Properties of Saliva in the Field of Dental Treatment. BioMed Research International [Internet]. 2018 May 9;1-13. https://doi.org/10.1155/2018/6572381

[20] Mohammadifar M, Choi S. A Papertronic, On-Demand and Disposable Biobattery: Saliva-Activated Electricity Generation from Lyophilized Exoelectrogens Preinoculated on Paper. Advanced Materials Technologies [Internet]. 2017 Jul 20;2(9):1-9. https://doi.org/10.1002/admt.201700127

[21] Kasper JC, Friess W. The freezing step in lyophilization: Physico-chemical fundamentals, freezing methods and consequences on process performance and quality attributes of biopharmaceuticals. European Journal of Pharmaceutics and Biopharmaceutics [Internet]. 2011 Jun;78(2):248-63. https://doi.org/10.1016/j.ejpb.2011.03.010

[22] Kumar R, Singh L, Zularisam AW. Exoelectrogens: Recent advances in molecular drivers involved in extracellular electron transfer and strategies used to improve it for microbial fuel cell applications. Renewable and Sustainable Energy Reviews [Internet].
2016;56:1322-36. https://doi.org/10.1016/i.rser.2015.12.029

[23] Khunti K. Near-patient testing in primary care. British Journal of General Practice [Internet]. 2010;60(572):157-8. https://doi.org/10.3399/bjgp10X483454

[24] Hajar R. Diabetes as "coronary artery disease risk equivalent": A historical perspective. Heart Views [Internet]. 2017 Jan;18(1):34.

https://doi.org/10.4103/heartviews.heartviews_37_17

[25] Alhajj M, Farhana A. Enzyme Linked Immunosorbent. In: StatPearls [Internet]. StatPearls; 2021 [cited 2021 Mar 30]. Available from: https://www.ncbi.nlm.nih .gov/books/NBK555922/

[26] Fitzgerald J, Fenniri H. Cutting Edge Methods for Non-Invasive Disease Diagnosis Using E-Tongue and E-Nose Devices. Biosensors [Internet]. 2017;7(4):59. https://doi.org/10.3390/bios7040059

[27] Clark DP, Pazdernik NJ. Environmental Biotechnology. Biotechnology [Internet]. 2016;393418. https://doi.org/10.1016/b978-0-12-3850157.00012-0

[28] Fuel Cells [Internet]. Energy.gov. Office of Energy Efficiency \& Renewable Energy; [cited 2021 Mar 31]. Available from: https://www.energy.gov/eere/fuelcells/ fuel-cells

[29] Logan BE, Hamelers B, Rozendal R, Schröder U, Keller J, Freguia S, et al. Microbial Fuel Cells: Methodology and Technology†. Environmental Science \& Technology [Internet]. $2006 \mathrm{Jul}$ 14;40(17):5181-92. https://doi.org/10.1021/es0605016

[30] Dawes C. How Much Saliva Is Enough for Avoidance of Xerostomia? Caries Research [Internet]. 2004;38(3):236-40. https://doi.org/10.1159/000077760

[31] Mink JE, Qaisi RM, Logan BE, Hussain MM. Energy harvesting from organic liquids in micro-sized microbial fuel cells. NPG Asia Materials [Internet]. 2014 Mar 7;6(3). https://doi.org/10.1038/am.2014.1

[32] University Y, Kariis H, Pohl A, Persson P, Ojamäe L. The electronic structure and reflectivity of PEDOT:PSS from density functional theory. Chemical Physics [Internet]. 2011;384(1-3):44-51. https://doi.org/10.1016/j.chemphys.2011.05.003

[33] Cheng S, Liu H, Logan BE. Power Densities Using Different Cathode Catalysts (Pt and CoTMPP) and Polymer Binders (Nafion and PTFE) in Single Chamber Microbial Fuel Cells. Environmental Science \& Technology [Internet]. 2006;40(1):364-9. https://doi.org/10.1021/es0512071

[34] Mansoorian HJ, Mahvi AH, Jafari AJ, Amin MM, Rajabizadeh A, Khanjani N. Bioelectricity generation using two chamber microbial fuel cell treating wastewater from food processing. Enzyme and Microbial Technology [Internet]. 2013 May 10;52(67):352-7.

https://doi.org/10.1016/j.enzmictec.2013.03.004 
UNDERGRADUATE RESEARCH IN NATURAL AND CLINICAL SCIENCE AND TECHNOLOGY (URNCST) JOURNAL

Read more URNCST Journal articles and submit your own today at: https://www.urncst.com

[35] Malon RS, Sadir S, Balakrishnan M, Córcoles EP. Saliva-Based Biosensors: Noninvasive Monitoring Tool for Clinical Diagnostics. BioMed Research International [Internet]. 2014;1-20. https://doi.org/10.1155/2014/962903

[36] Thomas GP. High Performance Liquid Chromatography (HPLC) - Methods, Benefits and Applications [Internet]. AZoM.com. 2013 [cited 2021 Mar 31]. Available from: https://www.azom.com/ article.aspx?ArticleID $=8468$

[37] Mustakeem. Electrode materials for microbial fuel cells: nanomaterial approach. Materials for Renewable and Sustainable Energy [Internet]. 2015 Nov 5;4(4). https://doi.org/10.1007/s40243-015-0063-8

[38] Lasisi TJ, Lawal FB. Preference of saliva over other body fluids as samples for clinical and laboratory investigations among healthcare workers in Ibadan, Nigeria. Pan African Medical Journal [Internet]. 2019 Dec 11;34. https://doi.org/10.11604/pamj.2019.34.191.18738

[39] Scientific A. Urine Drug Test vs. Saliva Drug Test [Internet]. ALFA. 2019 [cited 2021 Mar 31]. Available from: https://www.alfascientific.com/industry-update/ urine-drug-test-vs-saliva-drug-test/

[40] Khurshid Z. Salivary point-of-care technology. European Journal of Dentistry [Internet]. 2018;12(01):001-2. https://doi.org/10.4103/ejd.ejd 376 17

[41] McDonald J, Dean S, Niewolny D, Garcia D, Chhabra $\mathrm{N}$, Chang L. [Internet]. Integrated Circuits for Implantable Medical Devices Aug, 2011. Available from: https://www.nxp.com/docs/en/white-paper/ ICIMDOVWP.pdf

[42] Price CP. Regular review: Point of care testing. BMJ [Internet]. 2001 May 26;322(7297):1285-8. https://doi.org/10.1136/bmj.322.7297.1285
[43] Malamud D. Saliva as a Diagnostic Fluid. Dental Clinics of North America [Internet]. 2011;55(1):159-78. https://doi.org/10.1016/j.cden.2010.08.004

[44] Kim BH, Chang IS, Gadd GM. Challenges in microbial fuel cell development and operation. Applied Microbiology and Biotechnology [Internet]. 2007;76(3):485-94. https://doi.org/10.1007/s00253007-1027-4

[45] Logan BE, Regan JM. Microbial Fuel CellsChallenges and Applications. Environmental Science \& Technology [Internet]. 2006 Sep 1;40(17):5172-80. https://doi.org/10.1021/es0627592

[46] 20.7: Batteries and Fuel Cells [Internet]. Chemistry LibreTexts. Libretexts; 2021 [cited 2021 Mar 31]. Available from: https://chem.libretexts.org/ Bookshelves/General_Chemistry/Map\%3A Chemistry _- The Central_Science_(Brown_et_al.)/20\%3A Electrochemistry/20.7\%3A_Batteries_and_Fuel_Cells

[47] Buzhardt L. Dealing with Drooling [Internet]. vca_corporate. [cited 2020 Aug 20]. Available from: https://vcahospitals.com/know-your-pet/dealing-withdrooling

[48] Cavitron Ultrasonic Teeth Cleaning: Albert Lea, MN: Uptown Dental [Internet]. Uptown Dental | Uptown Dental- Albert Lea Dentist. 2018 [cited 2021 Mar 31]. Available from: https://uptowndental.org/cavitronultrasonic-teeth-cleaning/

[49] Deaton J. Scientists have developed a battery that gets its power from human spit [Internet]. Business Insider. Business Insider; 2017 [cited 2020 Aug 20]. Available from: https://www.businessinsider.com/scientists-havedeveloped-a-battery-that-gets-power-from-human-spit$\underline{2017-8}$

\section{Article Information}

Managing Editor: Jeremy Y. Ng

Peer Reviewers: Bi-Ru Amy Yeung, Ramis Arbi

Article Dates: Received Mar 03 21; Accepted May 18 21; Published Jun 0421

\section{Citation}

Please cite this article as follows:

Dhall K, Rajasuresh K. Analyzing the properties of saliva to act as a viable fuel source and its capabilities to interact with microbial fuel cell (MFC) powered theoretical diagnostic devices beneficial to low-income communities. URNCST Journal. 2021 Jun 04: 5(6). https://urncst.com/index.php/urncst/article/view/261

DOI Link: https://doi.org/10.26685/urncst.261 
UNDERGRADUATE RESEARCH IN NATURAL AND CLINICAL SCIENCE AND TECHNOLOGY (URNCST) JOURNAL

Read more URNCST Journal articles and submit your own today at: https://www.urncst.com

\section{Copyright}

(C) Krisha Dhall, Krismaa Rajasuresh. (2021). Published first in the Undergraduate Research in Natural and Clinical Science and Technology (URNCST) Journal. This is an open access article distributed under the terms of the Creative Commons Attribution License (https://creativecommons.org/licenses/by/4.0/), which permits unrestricted use, distribution, and reproduction in any medium, provided the original work, first published in the Undergraduate Research in Natural and Clinical Science and Technology (URNCST) Journal, is properly cited. The complete bibliographic information, a link to the original publication on http://www.urncst.com, as well as this copyright and license information must be included.
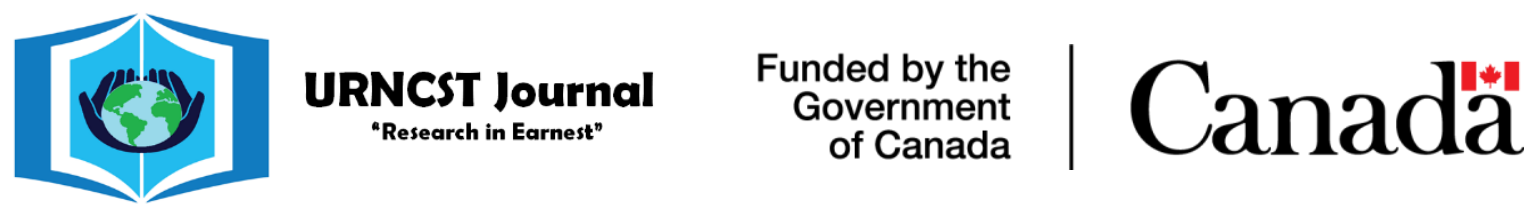

Do you research in earnest? Submit your next undergraduate research article to the URNCST Journal!

| Open Access | Peer-Reviewed | Rapid Turnaround Time | International | | Broad and Multidisciplinary | Indexed | Innovative | Social Media Promoted |

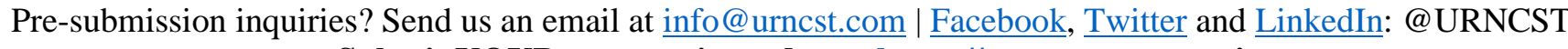

Submit YOUR manuscript today at https://www.urncst.com! 